\title{
The U.S. Islamophobia Network: Its Funding and Impact
}

\section{Corey Saylor}

Council on American-Islamic Relations

ISLAMOPHOBLA STUDIES JOURN AL
VOLUME 2, NO. 1, SPRING 2014, PP. 99-xx.

Published by:

Islamophobia Research and Documentation Project,

Center for Race and Gender, University of California, Berkeley.

Disclaimer:

Statements of fact and opinion in the articles, notes, perspectives, etc. in the Islamophobia Studies Journal are those of the respective authors and contributors. They are not the expression of the editorial or advisory board and staff. No representation, either expressed or implied, is made of the accuracy of the material in this journal and ISJ cannot accept any legal responsibility or liability for any errors or omissions that may be made. The reader must make his or her own evaluation of the accuracy and appropriateness of those materials. 


\title{
The U.S. Islamophobia Network: Its Funding and Impact
}

\author{
Corey Saylor \\ Council on American-Islamic Relations
}

The U.S.-based Islamophobia network's inner core is currently comprised of at least 37 groups whose primary purpose is to promote prejudice against or hatred of Islam and Muslims. An additional 32 groups whose primary purpose does not appear to include promoting prejudice against or hatred of Islam and Muslims but whose work regularly demonstrates or supports Islamophobic themes make up the network's outer core.

The inner core of the U.S.-based Islamophobia network enjoyed access to at least $\$ 119,662,719$ in total revenue between 2008 and 2011. Groups in the inner core are often tightly linked. Key players in the network benefitted from large salaries as they encouraged the American public to fear Islam.

In 2011 and 2012, 78 bills or amendments designed to vilify Islamic religious practices were introduced in the legislatures of 29 states and the U.S. Congress. Sixty-two of these bills contained language that was extracted from David Yerushalmi's American Laws for American Courts (ALAC) model legislation. While the bias behind the bills is clear, the presence of an actual problem that needed solved was not, even to the legislators introducing the measures. In at least 11 states, mainstream Republican leaders introduced or supported anti-Muslim legislation.

In September 2013 the Council on American-Islamic Relations (CAIR), the nation's largest Muslim civil liberties and advocacy group, issued "Legislating Fear: Islamophobia and its Impact in the United States 2011-2012." In part, that report examines the revenue available to Islamophobic organizations and their legislative impact. This paper is extracted from that report.

\section{FINANCING PREJUDICE AND HATE}

According to research conducted by CAIR, the inner core of America's Islamophobia network enjoyed access to at least $\$ 119,662,719$ in total revenue between 2008 and 2011. Given the limitations on CAIR's research, this number should be viewed as very conservative.

Groups in the inner core are often tightly linked. For example, Daniel Pipes's Middle East Forum granted \$1,242,000 over three years to Steven Emerson's Investigative Project on Terrorism. Pamela Geller and Robert Spencer's American Freedom Defense Initiative and Jihad Watch share the exact same five top leaders.

Key players in the network benefitted from large salaries as they encouraged the American public to fear Islam. David Horowitz of the David Horowitz Freedom Center earned $\$ 488,953$ in 2011. As President/Treasurer of the board of directors of ACT! for America Brigitte Gabriel oversaw a 79 percent increase in her own compensation, going from $\$ 87,300$ in 2010 to $\$ 156,473$ in 2011 .

\section{BACKGROUND}


In 2011, the authors of the Center for American Progress Action Fund's Fear, Inc. examined the Islamophobia network's roots. They found seven foundations contributing $\$ 42.6$ million over a ten year period to organization's promoting anti-Islam sentiment in America. Fear, Inc. focused only on the funding coming through foundations while this report spotlights total revenue.

As a result of using similar primary source material a certain amount of repetition in the two reports' findings exists. CAIR has worked to minimize this repetition and focus on expanding the public's understanding of group's promoting Islamophobia in America. The authors of this report strongly encourage all readers to obtain Fear, Inc. as an essential resource for understanding the Islamophobia network.

A number of journalists have also already produced insightful material on this subject. For instance, it was Justin Elliot of Salon Magazine ${ }^{1}$ who first broke the news that Barre Seid is likely responsible for a $\$ 17$ million donation to the Clarion Fund to make its 2008 distribution of millions of copies of its anti-Muslim film Obsession possible. Similarly, The Tennessean's Bob Smeitana revealed questionable financial transactions between Steven Emerson's not-for-profit Investigative Project on Terrorism and for-profit SAE Productions.

\section{METHOD}

CAIR developed its American Islamophobe Database by reviewing the source material for both 2011's "Same Hate, New Target: Islamophobia and its Impact in the United States 2009-2010" and this report.

Groups and individuals cited in the reports and active in the last five years were entered into the database and then assigned to one of three categories:

Inner Core: Groups or individuals whose primary purpose is to promote prejudice against or hatred of Islam and Muslims and whose work regularly demonstrates Islamophobic themes.

Outer Core: Groups or individuals whose primary purpose does not appear to include promoting prejudice against or hatred of Islam and Muslims but whose work regularly demonstrates or supports Islamophobic themes.

Of Concern: Groups or individuals who have used Islamophobic themes or supported Islamophobia in America, but whose work does not regularly demonstrate or support Islamophobic themes. CAIR does not further discuss groups placed in this category in this report.

CAIR then obtained tax documents known as Form 990s for each non-profit organization in the inner core for the years 2008-2011, when they could be acquired in the window of time allotted for researching and writing this report. Form 990s must be filed annually by tax exempt organizations. Unless otherwise stated, all of the below information was obtained from these forms.

\section{THE INNER CORE}

CAIR identifies 37 groups in the Islamophobia network's inner core. The impact of eleven of these groups is local in nature. Five of the local groups are based in Florida: Americans Against Hate, Citizens for National Security, Counter Terrorism Operations 
Center, Florida Family Association and The United West. ACT! For America is headquartered in Florida as well.

The influence of these groups spans a full spectrum from minimal, such as the Sheepshead Bay, New York's Bay People, to significant, such as ACT! For America, the Center for Security Policy, Jihad Watch, Atlas Shrugs and the Investigative Project on Terrorism.

Groups in the Islamophobia Network's Inner Core

(Groups listed with a state abbreviation tend to operate only in that state.)

- ACT! For America

- American Freedom Defense Initiative

- American Freedom Law Center

- American Public Policy Alliance

- American-Islamic Forum for Democracy

- Americans Against Hate (Fla.)

- Atlas Shrugs

- Bare Naked Islam

- Bay People (N.Y.)

- Center for Security Policy

- Center for the Study of Political Islam

- Christian Action Network

- Citizens for National Security (Fla.)

- Concerned American Citizens (Calif.)

- Concerned Citizens for the First Amendment (Calif.)

- Counter Terrorism Operations Center (Fla.)

- David Horowitz Freedom Center

- Debbieshlussel.com (Mich.)

- Dove World Outreach Center

- Florida Family Association (Fla.)

- Former Muslims United

- Forum for Middle East Understanding

- Gates of Vienna

- Investigative Project on Terrorism

- Jihad Watch

- Middle East Forum

- Middle East Media Research Institute

- Militant Islam Monitor

- SAE Productions

- Society of Americans for National Existence

- Stop the Islamization of Nations

- Strategic Engagement Group

- Tennessee Freedom Coalition (Tenn.)

- The Clarion Fund 
- The Shoebat Foundation

- The United West (Fla.)

- The Virginia Anti-Shariah Taskforce (Va.)

\section{THE OUTER CORE}

CAIR identifies 32 groups in the Islamophobia network's outer core. Many of the listed foundations were identified by the Center for America Progress Action Fund in Fear, Inc. and are included because they funnel money to the network. Just as providing funds to white supremacist or anti-Semitic groups should be seen as anathema, these foundations must be held to socially responsible standards.

Groups in the Islamophobia Network's Outer Core

(Groups listed with a state abbreviation tend to operate only in that state.)

- American Center for Law and Justice

- American Family Association

- American Islamic Leadership Coalition

- Anchorage Foundation/William Rosenwald Family Fund

- Family Security Matters

- Becker Foundations

- Carroll County Republican Party (Tenn.)

- Christian Broadcasting Network

- Donors Capital Fund

- Eagle Forum

- Endowment for Middle East Truth

- Extreme Terrorism Consulting

- Fairbrook Foundation

- Fox News

- Grace Baptist Church (Tenn.)

- Liberty Counsel

- Lynde and Harry Bradley Foundation

- National Review

- Richard Mellon Scaife Foundations

- Russell Berrie Foundation

- Rutherford Reader (Tenn.)

- Security Solutions International

- Stewart County Republican Party (Tenn.)

- Traditional Values Coalition

- The Family Leader

- The Mark Levin Show

- The Oak Initiative

- The Rush Limbaugh Show

- The Savage Nation 
- Washington Times

- Williamson County Republican Party (Tenn.)

- Worldnet Daily

\section{NETWORK INTERDEPENDENCE}

Daniel Pipes and his Middle East Forum (MEF) are longstanding components of the Islamophobia network. Pipes's involvement in anti-Muslim sentiment is documented back to his 1990 statement raising concerns about "brown-skinned people" with "different standards of hygiene" immigrating to America.

MEF's funding activities provide an illuminating example of the interconnected nature of the Islamophobia network:

- Steve Emerson's Investigative Project on Terrorism received \$1,242,000 from MEF between 2009 and 2011.

- Between 2009 and 2011 MEF sent Yigal Carmon’s Middle East Media Research Institute (MEMRI) \$450,000.

- Frank Gaffney's Center for Security Policy got $\$ 60,000$ in 2009.

- The Committee for Accuracy on Middle East Reporting, or CAMERA, received two grants totaling \$70,000, one in 2009 and the other in 2011.

- David Horowitz's Freedom Center, which in turn funds Robert Spencer's Jihad Watch, got $\$ 6,000$ in 2009 .

- Zuhdi Jasser's American Islamic Forum for Democracy accepted \$10,000 from MEF in 2010.

- Outer core group the Endowment for Middle East Truth, on whose board Pipes serves, received a $\$ 75,000$ grant from MEF in 2010.

\section{Daniel Pipes's Middle East Forum Grants to Islamophobia Network Organizations}

\begin{tabular}{|l|r|r|r|r|}
\hline Organization & $\mathbf{2 0 0 9}$ & $\mathbf{2 0 1 0}$ & $\mathbf{2 0 1 1}$ & Total \\
\hline Middle East Media Research Institute & 200,000 & 100,000 & 150,000 & $\$ 450,000$ \\
\hline Investigative Project on Terrorism & 250,000 & 480,000 & 512,000 & $\$ 1,242,000$ \\
\hline Center for Security Policy & 60,000 & & & $\$ 60,000$ \\
\hline Committee for Accuracy on Middle East Reporting & 50,000 & & 20,000 & $\$ 70,000$ \\
\hline David Horowitz Freedom Center & 6,000 & & & $\$ 6,000$ \\
\hline American Islamic Forum for Democracy & & 10,000 & & $\$ 10,000$ \\
\hline Endowment for Middle East Truth & & 75,000 & & $\$ 75,000$ \\
\hline
\end{tabular}

Similarly, the David Horowitz Freedom Center is intertwined with Pamela Geller and Robert Spencer. In turn, Geller and Spencer are hand-in-hand: each member of Jihad Watch's board of directors is listed on the American Freedom Defense Initiative's web site as a "global leader." 
Jihad Watch filed as a non-profit organization in 2007, reporting $\$ 0$ in revenue on its Form 990. Its most recent 990s cover 2010 and 2011.

Jihad Watch does, however, appear on the David Horowitz Freedom Center's 2009 Form 990. Acknowledged as a 'program' of the Center, Jihad Watch accrued over $\$ 300,000$ in expenses with $\$ 0$ in revenue. Spencer is listed as an employee of the Freedom Center with the title Jihad Watch Director.

In 2010, Jihad Watch is again listed as a Freedom Center program, and Spencer is still an employee. But in 2010, Jihad Watch also filed separately as a nonprofit, this time with revenue and grants over $\$ 190,000$. On this form, Spencer is listed as Jihad Watch's VicePresident, claiming no compensation whatsoever. This form 990 also lists Pamela Geller as Jihad Watch's president, while at the same time listing Geller and Spencer's other organization, The American Freedom Defense Initiative, as the recipient of a $\$ 70,933$ "payment to an affiliate" from Jihad Watch.

Jihad Watch continues to be listed as a program of the Horowitz Freedom Center in 2011, this time receiving its own separate $\$ 95,000$ grant. Again Spencer is the "Director of Jihad Watch" raking in a salary of $\$ 161,206$ from the Center. Jihad Watch's most recent, separately listed 990 reports increased grants and revenue, reaching over $\$ 238,000$. Jihad Watch granted American Freedom Defense Initiative \$16,624 that year, while still listing Geller as their President and Spencer as their VP.

Geller and Spencer represent a wide array of inner core staples: American Freedom Defense Initiative (as the two top global leaders), Atlas Shrugs (Geller's blog), the David Horowitz Freedom Center (Spencer's employer), ${ }^{3}$ Jihad Watch (both are board members) and Stop the Islamization of Nations. They are not the only people serving multiple parts of the network.

Nina Cunningham is the founder and CEO of Quidlibet Research, ${ }^{4}$ a legal consulting firm. She serves on the boards of the Center for Security Policy, the David Horowitz Freedom Center, and also the Clarion Fund. She is also a director at the Endowment for Middle East Truth.

Claire Lopez, a former national security professional, is a member of the Clarion Fund board of advisors, a United West board member and Center for Security Policy fellow.

David Steinmann is listed as the Vice Chairman of Daniel Pipes's Middle East Forum and also serves on the board of Frank Gaffney's Center for Security Policy. The Committee on Fairness and Accuracy in Middle East Reporting in America (CAMERA) lists him as a director. In addition to these institutes, Steinmann is also the president of treasurer of the William Rosenwald Family Fund, of which Fear, Inc. reports that between "2001 and 2008, the Anchorage Charitable Fund and William Rosenwald Family Fund contributed $\$ 2,818,229$ to Islamophobic organizations."

Dr. Ashraf Ramelah's advocacy for Coptic Christians, a group facing discrimination in too many places around the world, is undermined by his alliance with the Islamophobia network and his propagation of misinformation about Islamic religious principles. For example, during his speech at Stop the Islamization of Nations' 2012 International Freedom of Speech Congress Ramelah defended Robert Spencer and Pamela Geller saying "a lot of America (is) calling us bigot(ed) and Islamophobic, no, we (are) saying the truth and the truth hurt(s)." When speaking about the September $11^{\text {th }}$ attacks he said "they are not terrorists, they are jihad. They are for the Quran." Ramelah is a board member of Stop the Islamization of Nations, of which he says "I believe this... global organization will be the first organization to counter Islam in... every country in the world and we will win." 5 Along with his position on SION's board, he is also the president of Voice of the Copts, a human 
rights organization, and a contributing editor of Family Security Matters, a conservative news source sponsored by Center for Security Policy.

\section{EXAMPLES OF AFFLUENT SUPPORTERS OF THE NETWORK}

\section{Foster Friess}

Foster Friess made his fortune in mutual funds. His super PAC donations gave life to former Pennsylvania Senator Rick Santorum's 2012 GOP presidential nomination bid. Santorum explicitly endorsed profiling of Muslims during a presidential debate.

On his website, Friess lists among his key issues "helping peaceful Muslims ... to transcend the 7th century ideology of violence, intimidation, and coercion that threatens them ... and us." ${ }^{6}$ Leading the cause, according to Friess, are inner core groups such as Brigitte Gabriel and ACT! for America, Dr. Zuhdi Jasser and the American Islamic Forum for Democracy, Frank Gaffney and the Center for Security Policy, and Jihad Watch. Outer core groups such as Family Security Matters are also feature. Islamophobes such as Ayan Hirsi Ali and Dr. Wafa Sultan are also endorsed by Friess.

\section{Loyce and Aubrey Chernick}

In 2010, Politico found that "the lion's share of the $\$ 920,000$ [the David Horowitz Freedom Center] provided over the past three years to Jihad Watch came from [Joyce] Chernick, whose husband, Aubrey Chernick has a net worth of $\$ 750$ million." 7 Aubrey Chernick is a software engineer. ${ }^{8}$

According to the Center for American Progress Action Fund, Aubrey Chernick's Fairbrook Fund donated $\$ 1,498,450$ to elements of the Islamophobia network from 2004 to 2009.

\section{Pat Robertson}

On his 700 Club program, Robertson, a wealthy televangelist, is known for making comments asserting that "Islam is Satanic," "Islam is not a religion," and that "Muslims are worse than Nazis."

\section{Andy Miller}

Miller is Chief Executive Officer of Nashville's Healthmark Ventures. According to the Center for Responsive Politics, Miller was the sole contributor to the Citizens 4 Ethics in Government super PAC. His gift totaled $\$ 105,000$. Miller is active in Tennessee Republicanparty politics heading "fundraising and get-out-the-vote efforts as chairman of the 2010 Tennessee Victory Leadership Team and is a member of the Williamson County GOP Chairman's Circle."

Miller's gift to Citizens 4 Ethics in Government was used to support Lou Ann Zelenik's run for U.S. Congress. Speaking about his opposition to Rep. Diane Black (RTenn.) Miller said, "I don't think she believes there is a problem with Islam.",

\section{Others of Note}

As cited earlier, numerous press reports point to Chicago-based Barre Seid as the source of a $\$ 17$ million donation that enabled the Clarion Fund to distribute 28 million free copies of its anti-Islam film Obsession in battleground states in the run up to the 2008 election. ${ }^{11}$ 
Bob Vander Plaats is the president and CEO of The Family Leader. In 2011, the Hill newspaper, one of two key Capitol Hill publications, named Vander Plaats' endorsement as one of the top 10 coveted endorsements for Republicans running for president. ${ }^{12} \mathrm{He}$ eventually endorsed Rick Santorum. The Family Leader's 2012 election Marriage Vow contained both anti-Islam language, and in its original form including language that implied that African-Americans were better off during the slavery-era than under President Barak Obama's administration.

\section{LEADERSHIP COMPENSATION}

Leaders of the Islamophobia network are generally well-compensated for their efforts, often enjoying salary increases that far surpass those anticipated by members of the general workforce.

As President/Treasurer of the board of directors of ACT! for America Brigitte Gabriel oversaw a 79 percent increase in her own compensation, going from $\$ 87,300$ in 2010 to $\$ 156,473$ in 2011 . Robert Spencer, whose compensation does not reflect earnings from his numerous books, got a 17 percent raise from his employers at the David Horowitz Freedom Center in 2011. Both David Horowitz and Daniel Pipes benefitted from at least a 12 percent compensation increase in 2011.

Sample Compensation of Inner Core Leaders

\begin{tabular}{|c|c|c|c|c|c|}
\hline Organization & Name & Title & 2010 Compensation & 2011 Compensation & Increase \\
\hline ACT! for America & Guy Rogers & Executive Director & $\$ 100,606$ & $\$ 101,322$ & $0.7 \%$ \\
\hline ACT! for America & $\begin{array}{l}\text { Brigitte } \\
\text { Gabriel }^{13}\end{array}$ & $\begin{array}{c}\text { Board } \\
\text { President/Treasurer }\end{array}$ & $\$ 87,300$ & $\$ 156,473$ & $79 \%$ \\
\hline $\begin{array}{l}\text { David Horowitz } \\
\text { Freedom Center }\end{array}$ & Robert Spencer & Jihad Watch Director & $\$ 138,004$ & $\$ 161,206$ & $17 \%$ \\
\hline $\begin{array}{l}\text { David Horowitz } \\
\text { Freedom Center }\end{array}$ & $\begin{array}{c}\text { David } \\
\text { Horowitz }\end{array}$ & Founder/CEO & $\$ 435,963$ & $\$ 488,953$ & $12 \%$ \\
\hline $\begin{array}{c}\text { Center for Security } \\
\text { Policy }\end{array}$ & Frank Gaffney & Founder/President & $\$ 299,063$ & $\$ 278,300$ & $-7 \%$ \\
\hline $\begin{array}{l}\text { Middle East Media } \\
\text { and Research } \\
\text { Institute }\end{array}$ & Yigal Carmon & President and Founder & $\$ 163,690$ & & $\begin{array}{c}\text { Not } \\
\text { available }\end{array}$ \\
\hline $\begin{array}{l}\text { Middle East } \\
\text { Forum }\end{array}$ & Daniel Pipes & President & $\$ 200,000$ & $\$ 224,992$ & $12.5 \%$ \\
\hline
\end{tabular}




\section{AMERICAN LAWS FOR AMERICAN COURTS AND ITS DERIV ATIVES}

David Yerushalmi, is an attorney with inner core groups the Center for Security Policy and the American Freedom Law Center. He is confident in his hatred of Islam, writing, "Our greatest enemy today is Islam. The only Islam appearing in any formal way around the world is one that seeks a world Caliphate through murder, terror and fear." 14 Yerushalmi is also a founder of the Society of Americans for National Existence, a group that once advanced a policy advocated incarceration for "adherence to Islam."

$\mathrm{He}$ is also the author of American Laws for American Courts (ALAC), the template for many anti-Islam bills introduced across the nation.

Outside of his anti-Islam activism Yerushalmi is notable for writing, "There is a reason the founding fathers did not give women or black slaves the right to vote." Yerushalmi also says he finds truth in the view that Jews destroy their host nations like a fatal parasite. ${ }^{15}$

Yerushalmi wrote the bill for the American Public Policy Alliance (APPA). While the organization has a professional-looking website, its Washington, D.C. address is a UPS Store. APPA has a minor Facebook presence, with less than 100 friends as of early 2013.

Yerushalmi's bill is then pushed at the state-level by groups like ACT! for America, the Eagle Forum and to a lesser extent Pamela Geller's Stop the Islamization of America.

In its 2011 IRS filings, ACT! for America includes among the organization's accomplishments a total membership of 175,000 people, 635 chapters, and 40,000 Facebook fans. The group also celebrates its role in the passage of anti-Islam bills in Arizona and Tennessee. Also among its accomplishments ACT! lists the distribution of thousands of "Sharia Law for Non-Muslim" [sic] pamphlets and the hosting of multiple events at which participants were inaccurately taught "how the Islamic doctrine of abrogation, which is the annulling of contradictory passages in the Koran, has annulled up to 124 peaceful and superseded them with violent and jihadist verses aimed at non-Muslims."

ACT! for America founder Brigitte Gabriel once told the Australian Jewish News: "Every practicing Muslim is a radical Muslim." ${ }^{16}$ Speaking at the Intelligence Summit in Washington, D.C. on February 19, 2006, Gabriel told the audience, "America and the West are doomed to failure in this war unless they stand up and identify the real enemy. Islam."

In a newsletter the Eagle Forum told its supporters, "Sharia law is becoming part of the American landscape as Christianity is being systematically removed. Christian students are being told they cannot pray at school activities or even pray in front of American institutions, while public school students adopt Muslim names, pray on prayer rugs and celebrate Ramadan under a state-mandated curriculum." ${ }^{17}$ Tennessee's anti-Islam bill was given to legislators by Tennessee Eagle Forum President Bobbie Patray. ${ }^{18}$ Texas Eagle Forum president Pat Carlson testified in favor of that state's anti-Islam bill. ${ }^{19}$

In December 2012, an Alaska ethics panel recommended that Karen Sawyer, former chief of staff to state Rep. Carl Gatto, be fired after it found "she used state resources to help an anti-Islamic group." The panel also recommended that Sawyer never be allowed to work for the legislature again. Sawyer resigned before she could be fired. According to the panel's findings, Sawyer allowed David Heckert of Stop Islamization of America to "use the Wasilla legislative information office and equipment for work related to his organization." It also found that Sawyer used state equipment to help plan activities related to a 2011 group conference, and that she failed to file a timely disclosure showing she was a member of the group's board in 2011 and 2012." The Associated Press also noted that the panel found that 
SIOA's "main mission appeared to be promoting their organization and its mission with HB88 [Alaska’s anti-Islam bill] as a validation point."

\section{BILL BREAKDOWNS}

In 2011 and 2012, 78 bills or amendments designed to vilify Islamic religious practices were introduced in the legislatures of 29 states and the U.S. Congress. Sixty-two of these bills contained language that was extracted from ALAC.

Party of bills' original sponsor(s)

- 73 bills were introduced by Republicans

- 1 bill was introduced by a Democrat (Alabama)

- 3 were bi-partisan (Kansas, South Carolina, South Dakota)

- 1 was introduced by Republicans along with an Independent who caucuses with the Republicans (South Dakota)

Number of bills that used language of Islamophobe David Yerushalmi

- 62 were based on David Yerushalmi’s American Law for American Courts

- 16 were not

Bills were signed into law in Arizona, Kansas, South Dakota and Tennessee in 2011 and 2012. These joined previously passed bills in Oklahoma and Louisiana bringing the total to six states with an anti-Islam law on the books.

\section{WHAT IS SHARIA?}

Sharia literally means "path." It is a set of interpretations of the Quran and other Islamic sources; it is dynamic and intended to accommodate the time, place and laws-in America that means the U.S. Constitution—of a particular community. ${ }^{20}$ Sharia is interpreted differently based on its surroundings. Sharia mandates Muslims to respect the law of the land in which they live.

\section{IS SHARIA TAKING OVER?}

According to the Public Religion Research Institute, as of September 2012, 61 percent of Americans reject the notion that American Muslims are seeking to establish Sharia as the law of the land. The number of Americans who feel that Muslims are working to subvert the Constitution rose from 23 percent in February 2012 to 30 percent in September 2012. ${ }^{21}$

No religious code can replace American law. Article VI, Clause 2 of the U.S. Constitution clearly states, "This Constitution...shall be the supreme law of the land; and the judges in every state shall be bound thereby. ..." Additionally, the First Amendment prohibits Congress from making any law "respecting an establishment of religion. ..."

America has an already established tradition of allowing people of faith to make agreements and resolve disputes within the parameters of their religion, as long as any resulting contract complies with U.S. law. Catholic Canon law and Jewish Halacha are the most frequently cited examples in the context of the debate surrounding Islamic practices. 
No national Muslim organization is calling for the implementation of foreign law in the United States. Many support the idea that individuals can make faith-based agreements that are in accordance with U.S. law which can subsequently be enforced by U.S. courts. A primary example of this is the Islamic mortgage industry. Corporations offer loans that are compliant with both Islamic rules against lending money with interest and with American law. These contracts can, if necessary, be enforced in a U.S. court of law.

In 2011, the American Bar Association (ABA) passed a resolution opposing ALACtype legislation noting that it is "duplicative of safeguards that are already enshrined in federal and state law," and saying, "Initiatives that target an entire religion or stigmatize an entire religious community, such as those explicitly aimed at 'Sharia law,' are inconsistent with some of the core principles and ideals of American jurisprudence."

The ABA also stated the following:

Language in these Bills and Amendments dealing with 'international law' or 'foreign and customary law' is likely to have an unanticipated and widespread negative impact on business, adversely affecting commercial dealings and economic development in the states in which such a law is passed and in U.S. foreign commerce generally.

And furthermore,

Many of the Bills and Amendments would infringe federal constitutional rights, including the free exercise of religion and the freedom of contract, or would conflict with the Supremacy Clause and other clauses of the Constitution.

Regarding the notion of Islamic rules supplanting American law, the American Civil Liberties Union reached the following conclusion in a report released in May 2011:

A new report by the ACLU, Nothing to Fear: Debunking the Mythical "Sharia Threat" to Our Judicial System, examines, in detail, the cases repeatedly cited by antiMuslim groups as evidence of the alleged "Sharia threat" to our judicial system. The report concludes that these cases do not stand for the principles that anti-Muslim groups claim. Rather, these court cases deal with routine matters, such as religious freedom claims and contractual disputes. Courts treat these lawsuits in the same way that they deal with similar claims brought by people of other faiths. So instead of the harbingers of doom that anti-Muslim groups make them out to be, these cases illustrate that our judicial system is alive and well, and operating as it should.

The Anti-Defamation League wrote of the 2012 anti-Islam bill in Florida that there "simply is no documentation of unconstitutional application of foreign law in our judicial system. Florida courts are already prohibited from applying or considering religious law in any way that would constitute government entanglement with religion due to the separation of church and state embodied in the Florida and federal constitutions." ${ }^{22}$ The Florida Bar's Family Law Section made a similar argument. ${ }^{23}$

The Congressional Research Service, a nonpartisan component of the Library of Congress that does research for members of Congress, determined that, "Any bill that would specifically ban sharia may be challenged as a disapproval of Islam in violation of the 
Establishment Clause or as an infringement on the ability of Muslims to freely exercise their beliefs under the Free Exercise Clause." ${ }^{24}$

Similarly, Think Progress reported, "As the Supreme Court explained in Church of Lukumi Babalu Aye v. Hialeah, "the protections of the Free Exercise Clause pertain if the law at issue discriminates against some or all religious beliefs or regulates or prohibits conduct because it is undertaken for religious reasons.",25

As will be shown momentarily, the legislators who introduced anti-Islam bills also failed to produce evidence of an actual problem they felt would be addressed by such a law.

\section{THE PURPOSE OF AMERICAN LAW FOR AMERICAN COURTS}

Writing in the New York Times, reporter Andrea Elliot concluded that actually passing ALAC was a "secondary concern" for David Yerushalmi. "If this thing passed in every state without any friction, it would have not served its purpose," Yerushalmi told Elliot. "The purpose was heuristic — to get people asking this question, "What is Shariah?"'26

While most of these bills failed, many politicians found that the anti-Sharia issue draws attention to them and taps into public fear.

Yerushalmi wrote the model legislation to "get people asking this question." What he achieved was an anti-Muslim dialogue characterized by religious intolerance and the absence of an actual problem that was supported by a troubling number of mainstream state-level Republican leaders.

\section{RELIGIOUS INTOLERANCE}

It is reasonable to argue that the anti-Sharia movement is really a cover for Islamophobic sentiment. Bill supporters often argue that their legislation is meant to preserve American law, but this argument does not withstand even minimal scrutiny.

Writing in The Guardian, journalist Sarah Posner identified the main themes running through the movement: ${ }^{27}$

The conspiracy theory about sharia law is fivefold: that the goal of Islam is totalitarianism; that the mastermind of bringing this totalitarianism to the world is the Muslim Brotherhood, the grandfather of all Islamic groups from Hamas to the Islamic Society of North America; that these organizations within the US are traitors in league with the American left and are bent on acts of sedition against America; that the majority of mosques in the US are run by imams who promote such sedition; and that through this fifth column sharia law has already infiltrated the US and could result in a complete takeover if not stopped.

Writing about an anti-Islam bill in Florida, reporter Paul Berger noted in the Jewish Daily Forward on March 7, 2012, "The bill's supporters acknowledge that their proposal is aimed at Muslims." Berger went on to state that, if passed, the law might end up "preventing Orthodox couples from using Jewish religious courts, or batei din, to arbitrate their divorces, according to legal specialists and some Jewish groups."

On May 11, 2012 the Topeka Capital-Journal reported, "Sen. Chris Steineger, R-Kansas City, said a marketing campaign by supporters of the bill inundated him with materials that 'explain' why sharia law is coming and Muslims are trying to take over America." Steineger told the Capital-Journal, "The proponents of this measure, clearly by the literature they gave 
me and by the video link they directed me to, they presented this as protecting us against sharia law."

The Topeka Capital-Journal later reported, "But [Kansas state] House members left no doubt that the bill is largely about Islam. Rep. Janice Pauls, D-Hutchinson, told her colleagues it was important to vote for it to stave off Sharia - a view shared by Rep. Peggy Mast, R-Emporia. The bill passed 122-0 in the House."

Despite the bill's clear anti-Islam genesis, Virginia Delegate Rick Morris (R-64 ${ }^{\text {th }}$ district), who introduced a bill that echoed ALAC language, said, "It's definitely not an antiMuslim bill." A Virginia newspaper reported that Morris was telling his colleagues in the state legislature that the bill was intended to "apply American laws to family situations such as custody disputes, premarital agreements, divorce and the division of assets." 28

Virginia legislator Del. Bob Marshall (R-13 ${ }^{\text {th }}$ district) also argued that his bill did not target Islam. However, on February 12, 2012, Virginia-based constitutional professor Douglas Laycock told the Virginian-Pilot, "This one is more cautiously drafted than a lot of these bills because it doesn't mention Shariah law. Although everyone knows that's what it's about." Laycock then added, "You cannot be a state with commercial enterprises in a global economy and not deal with foreign law." Business interests and faith groups, such as the Jewish Community Federation, opposed the Virginia bill. ${ }^{29}$

"I would be less than fully honest with you if I didn't also say that part of the purpose of [House Bill] 1253 is to deal with what I am going to say generally has been referred to as Sharia law," said South Dakota State Representative Roger Hunt (R-10 ${ }^{\text {th }}$ district) before the State House Judiciary Committee. "[This bill] will give us the provision needed to in essence deal with religious codes that would be sought in the state of South Dakota."

In other places, legislators did not even attempt to hide the bias behind the bills they introduced.

In Tennessee, the bill's original definition of "Sharia" was, in practical terms, the entire religious tradition of Islam. "Sharia," read the bill as introduced, includes the "set of rules, precepts, instructions, or edicts" based upon sources from "the god of Allah or the prophet Mohammed." It stated that "Sharia" encompasses all content derived from "any of the authoritative schools of Islamic jurisprudence of Hanafi, Maliki, Shafi'i, Hanbali, Ja'afariya, or Salafi." Islam is split into two main branches, Sunni and Shia. Sunni Islam has four main schools of thought: Hanafi, Maliki, Shafi'i and Hanbali. Jafari is Shia Islam's main school of thought. Salafi is a movement within Sunni Islam. Thus, the above definition of Sharia both encompasses the vast majority of Muslims as well as reveals the author's unfamiliarity with the faith.

Rep. Carl Gatto (R-Palmer), Chairman of the Alaska State Legislature's House Judiciary Committee, said his proposed version of ALAC was necessary because of the religious beliefs of recent immigrants. "As a kid, we had Italian neighborhoods, Irish neighborhoods . . . but they didn't impose their own laws," Gatto said. He added, "When these neighborhoods are occupied by people from the Middle East, they do establish their own laws." Gatto later said, "I'm more concerned about cultures that are vastly different from European immigrants, who come here and prefer to maintain their specific laws from their previous countries, which are in violent conflict with American law. That's the issue that I am worried about." 30

South Dakota anti-Sharia bill sponsor Phil Jensen (R-District 33) told an audience, "It is alarming how many of our sisters and daughters who attend American universities are now marrying Muslim men." 31 
In Pennsylvania, the bill itself included no mention of Islam. However, in a memo to all House members urging them to co-sponsor the bill, Rep. RoseMarie Swanger (R-District 102) falsely claimed that Sharia is "inherently hostile to our constitutional liberties." Later, Swanger claimed she "had no idea how [the memo] was going to be written" and that it was never circulated. Swanger also claimed that it was leaked by "someone who is not my friend." 32 This claim is rather incredible, given that the memo, with Swanger's signature, was available on the Pennsylvania state legislature's website. ${ }^{33}$

Missouri State Rep. Don Wells (R-Cabool) referred to Sharia, as a "disease" like polio during a meeting of the House Judiciary Committee, which was discussing a bill Wells had proposed to ban consideration of Sharia in that state's courts. When another lawmaker asked if Wells really believed Sharia is like polio, he replied, "Absolutely."

Michigan State Rep. Dave Agema (R-Grandville) was clearly targeting Islam for unequal treatment in relation to other faiths. In explaining why he felt his bill was important, he told the Grand Rapids Press, "They [Muslims] want specific laws applied to their specific groups ... They do not want to be under our law." 34 Agema also repeated the myth that President Obama is secretly a Muslim.

In at least one instance, once a legislator was made aware of the bill's genesis, he withdrew it. Shortly after a press conference held by CAIR-Minnesota and interfaith groups, Republican State Senator Dave Thompson withdrew his bill, which had been written using American Laws for American Courts as a template, saying, "It was never my intent to introduce legislation that was being targeted to any one group." 35

\section{A NON-EXISTENT PROBLEM}

While the bias behind the bills is clear, the presence of an actual problem that needed solved was not, even to the legislators introducing the measures.

The Star Assistant in Alabama reported, "But no one-not even Sen. Gerald Allen, who sponsored the bill-can point to examples of Muslims trying to have Islamic law recognized in Alabama courts." "36 Allen could not even define Sharia when asked, saying "I don't have my file in front of me." When pressed about why the Alabama bill's definition of Sharia matched one found in Wikipedia, legislative staff "confirmed that the definition was in fact pulled from Wikipedia." ${ }^{37}$

Texas legislator Leo Berman said his bill was necessary because he had heard, but apparently had not actually tried to confirm, that one American town was allowing judges to use Sharia. "I heard it on a radio station here on my way into the Capitol one day. I don't know Dearborn, Michigan, but I heard [that Sharia is accepted there] on the radio. Isn't that true?"38

North Carolina legislator Rep. George Cleveland also was forced to admit, "I do not have any specific examples off the top of my head," when asked to show a need for his version of American Laws for American Courts. ${ }^{39}$

The pattern continued in South Carolina. "None of the senators nor Kevin A. Hall, a Columbia attorney who testified in support of the bill, were aware of any examples in South Carolina where courts upheld sharia law over the U.S. Constitution." ${ }^{40}$ When he was asked about Sharia in South Carolina, former State Attorney General Henry McMaster told an interviewer, "I haven't encountered anything except American law." 41

Sen. Mike Fair of South Carolina sponsored a version of Yerushalmi's bill in that state's Senate but admitted that he was, "not aware of any cases of foreign law being used in a South Carolina court." 42 
In Wyoming, Rep. Gerald Gay called his bill a "pre-emptive strike" since, according to the Billings Gazetteer, "No Wyoming court rulings have been based on Islamic law." Gay feared Wyoming judges might use Sharia to interpret "honor killings" and arranged marriages. ${ }^{43}$

Similarly, Georgia Rep. Mike Jacobs, vice chairman of Georgia's House Judiciary Committee and original sponsor of the American Laws for Georgia's Courts bill, "acknowledged that he was not aware of any instances in Georgia where a plaintiff or defendant asked the court to apply Sharia law but believes it has happened elsewhere." 44

The Kansas City Star's Jason Noble reported, "Missouri Reps. Paul Curtman and Don Wells agreed that there was no evidence that state courts were judging cases based on Islamic principles or foreign laws. ${ }^{45}$ Challenged again a month later, Curtman still could not provide an example.

Unlike many legislators, Kansas' Rep. Peggy Mast "provided numerous links to stories about Islamic courts in Britain and a print-out from the 'Islam Review' - a website that's stated purpose is 'to demonstrate that the fundamental teachings of Islam are incompatible with the Christian faith, and the American way of life.' However, like in other states, "Mast's research didn't turn up any instances of Kansas courts invoking Sharia."46

Missouri Speaker of the House Stephen Tilley also could not provide "an example of foreign law trumping domestic law in Missouri courts," reported Politicalmo.com in early March 2011. The article noted that Tilley's office later issued a statement outlining one case in New Jersey, but that ruling was rightfully overturned by a higher court.

Iowa state legislator Kim Pearson conceded that she did not "know of any cases of [Sharia deciding issues in Iowa courts] happening or how, under the Iowa and U.S. constitutions, it could." Nevertheless, Pearson's bill specifically targeted Islam for unequal treatment under the law.

\section{REPUBLICAN STATE-LEVEL LEADERS EMBRACE ANTI-ISLAM BILLS}

In at least 11 states, mainstream Republican leaders introduced or supported antiMuslim legislation. At least nine of those bills were based on Yerushalmi's American Laws for American Courts.

Oklahoma Governor Mary Fallin ignored the Constitution's proscription against government censure of religion when she threw her weight behind House Bill 1552, a version of Yerushalmi's model ALAC, saying, "I personally believe that a law should be made on American law, on our constitution. The people of Oklahoma spoke pretty clearly when there was a vote...on Sharia law...."47 A Federal judge recently determined that the vote Fallin was referring to resulted in a law that is un-Constitutional.

On March 2, 2012, MSNBC's Kari Huus reported “[South Dakota] Gov. Daugaard's general counsel Jim Seward testified that the bill served to 'answer the question of the Sharia law' without being unconstitutional or interfering with business interests. This bill was motivated by a growing demographic concern in Sioux Falls,' Seward said, referring to the influx of immigrants from majority Muslim countries."

Rep. Carl Gatto was chairman of the Alaska State Legislature's House Judiciary Committee when he sponsored an anti-Islam bill. Missouri Speaker of the House Stephen Tilley supported a bill. In South Dakota, original sponsor Charles Hoffman was majority whip. 
The originator of Michigan's anti-Muslim bill was Rep. Dave Agema, the majority caucus chair. Agema was elected as the national committeeman from Michigan to the Republican National Committee in May 2012.

\section{THE IMPACT OF THE BILLS}

\section{Legal Challenges}

The 2010 amendment to Oklahoma's state constitution, which prohibits courts from applying_-or even considering _ - "Sharia law" and "international law," explicitly subjected Islam to government censure. It immediately faced a legal challenge from then CAIROklahoma Executive Director Muneer Awad. A federal judge put the law on hold after determining that the challenge had merit and the law would likely be ruled unconstitutional.

In January, 2012, the U.S. Court of Appeals for the Tenth Circuit upheld the lower court's decision to block implementation of the Oklahoma state constitutional amendment. The appeals court ruling stated in part:

We conclude that Mr. Awad's allegation-that the proposed state amendment expressly condemns his religion and exposes him and other Muslims in Oklahoma to disfavored treatment — suffices to establish the kind of direct injury-in-fact necessary to create Establishment Clause standing. ... Appellants do not identify any actual problem the challenged amendment seeks to solve. Indeed, they admitted at the preliminary injunction hearing that they did not know of even a single instance where an Oklahoma court had applied Sharia law or used the legal precepts of other nations or cultures, let alone that such applications or uses had resulted in concrete problems in Oklaboma.

Speaking about the decision on MSNBC, CAIR staff attorney Gadier Abbas said, "It's not as if the 10th Circuit is a bastion of left-wing activism. This [ruling] is coming from a very conservative court ... [The court's ruling] is unequivocal that there are really serious, very clear violations of the Constitution that this amendment poses."

\section{Vilification of Islam}

To date, the only other observed impact of an enacted anti-Islam bill besides vilifying Islam during the process of passage is that it has no real world effect. In Tennessee, Rep. Judd Matheny and Sen. Bill Ketron's original, identical bills were revised and passed with all references to religion removed.

Similarly, the language of the final Arizona law has more symbolic than substantive impact. This observation substantiates our earlier assertion that legislators are spending their time passing laws to solve a non-existent problem. There is no wave of religious law being blocked by these anti-Islam bills because that wave does not exist.

\section{ENDNOTES}

1 Justin Elliott, “Mystery of Who Funded Right-Wing 'Radical Islam' Campaign Deepens,” Salon, November 16, 2010, available at: http://www.salon.com/2010/11/16/clarion_fund_obsession_dvds/. 
2 "Global Leaders", left sidebar, American Freedom Defense Initiative, available at: http://freedomdefense.typepad.com/fdi/.

3 “Staff," David Horowitz Freedom Center, available at: http://www.horowitzfreedomcenter.org/staff.

4 "Home," Quidlibet Research, Inc., available at: http://www.quidlibet.net/.

5 “Ashraf Ramelah, Spencer \& Geller: Stop Islamization of Nations' International Freedom Congress," YouTube video, posted by Pamela Geller, September 15, 2012, available at: http://www.youtube.com/watch?v=QRIgLwCfkdk.

6 "Helping Peaceful Muslims," Foster Friess: Encouraging Private Sector Solutions, available at: http:// fosterfriess.com/key-issues/helping-peaceful-muslims/.

${ }^{7}$ Ken Vogel and Giovanni Russonello, “The Park 51 Money Trail,” Politico, September 4, 2010, available at: http://www.politico.com/blogs/laurarozen/0910/The_Park51_money_trail.html.

${ }^{8}$ Max Blumenthal, “The Great Islamophobic Crusade,” CBS News, December 20, 2010, available at: http://www.cbsnews.com/2100-215_162-7166626.html.

9 Dan Glaun, “Anti-Islamic Activist Dumps $\$ 100 \mathrm{~K}$ into Tennessee Primary,” Open Secrets (blog), Center for Responsive Politics, July 20, 2012, ${ }^{9}$ available at: http://www.opensecrets.org/news/2012/07/anti-islam-activist-dumps-100-k-int.html.

10 Alex Isenstadt, “Sharia Law, Super PACs Roil GOP Primary,” Politico, July 29, 2012, available at: http://www.politico.com/news/stories/0712/79102.html.

11 Justin Elliott, “Mystery of Who Funded Right-Wing 'Radical Islam' Campaign Deepens,” Salon, November 16, 2010, available at: http://www.salon.com/2010/11/16/clarion_fund_obsession_dvds/.

${ }^{12}$ Michael O’Brien, “10 Coveted Endorsements for Republicans Running for President,” The Hill, June 25, 2011, available at: http://thehill.com/homenews/campaign/168393-10-coveted-endorsements-for-republicanpresidential-candidates.

${ }^{13}$ Listed as Brigitte Tudor.

${ }^{14}$ David Yerushalmi, "Newt's a Little Too Smart," The American Spectator, April 27, 2006, available at: http://spectator.org/archives/2006/04/27/ newts-a-little-too-smart.

${ }_{15}$ Doug Chandler and Larry Cohler-Esses, “Tables Turn on Arab School Critics," The New York Jewish Week, August 24, 2007, available at: http://www.thejewishweek.com/features/tables_turn_arab_school_critics_0.

${ }^{16}$ Clark Hoyt, “A Radical Islamophobe?”New York Times, August, 2008, available at: http://publiceditor.blogs.nytimes.com/2008/08/21/a-radical-

islamophobe $/$ ?scp $=4 \&$ sq $=\% 22$ brigitte $\% 20$ gabriel $\% 22 \&$ st $=$ cse.

17 Patricia Kilday Hart, “Texas Lawmakers Study Ban on Sharia Law," The Houston Chronicle, February 9, 2012, available at: http://www.chron.com/news/kilday-hart/article/Texas-lawmakers-study-ban-on-Sharia-law3220099.php.

18 Bob Smietana, “Tennessee Bill Would Jail Shariah Followers,” USA Today, February 23, 2011, available at: http://usatoday30.usatoday.com/news/nation/2011-02-23-tennessee-law-shariah_N.htm. 
${ }^{19}$ J. Patrick Pepper, "Dearborn Cited in Effort to Pass Anti-Sharia Law in Texas," Press and Guide, April 12, 2011, available at:

http://www.pressandguide.com/articles/2011/04/12/news/doc4da48b506b1a4425738775.txt.

${ }^{20}$ See "Sharia and Diversity: Why Americans are Missing the Point" by Institute for Social Policy

Understanding fellow Asifa Quraishi-Landes for a brief but excellent introduction to Sharia.

${ }^{21}$ Daniel Cox, E.J. Dionne, Jr., William A. Galston, and Robert P. Jones, What It Means to Be American: Attitudes in an Increasingly Diverse America Ten Years After 9/11 (Washington: Public Research Institute and Brookings Institute, September 6, 2011), available at: http://www.brookings.edu/ /media/research/files/reports/2011/9/06-americanattitudes/0906_american_attitudes.pdf..

22 Ashley Lopez, "CAIR Speaks Out Against 'Foreign Law' Bill Up in House Committee Tomorrow," The Florida Independent, February 21, 2012, available at: http:/ floridaindependent.com/70311/cair-sharia-foreignlaw-religion.

${ }^{23}$ Kenric Ward, “'Anti-Sharia law’ Bill Passes House Muslims, ACLU Object,” Sunshine State News, February 23 , 2012, available at: http://www.sunshinestatenews.com/story/anti-sharia-law-bill-passes-house-panel-muslimsaclu-object.

${ }^{24}$ Congressional Research Service, Application of Religious Law in U.S. Courts: Selected Legal Issues, by Cynthia Brougher, CRS Report R41824 (Washington: Office of Congressional Information and Publishing, May 18, 2011), available at: http://www.fas.org/sgp/crs/misc/R41824.pdf.

${ }^{25}$ Ian Millhiser, "South Dakota Governor Signs Unconstitutional Anti-Muslim Bill," ThinkProgress, March 13, 2012, available at: http://thinkprogress.org/justice/2012/03/13/443666/south-dakota-governor-signsunconstitutional-anti-muslim-bill/.

${ }^{26}$ Andrea Elliot, "The Man Behind the Anti-Shariah Movement," The New York Times, July 30, 2011, available at: http://www.nytimes.com/2011/07/31/us/31shariah.html?pagewanted=all\&_r=0.

27 Sarah Posner, "Sharia Threat Bandwagon Just Keeps Rolling On," The Guardian, March 16, 2011, available at: http://www.guardian.co.uk/commentisfree/belief/2011/mar/16/sharia-threat-bandwagon-king-hearing. 28 Julian Walker and Kathy Adams, "Critics: Bill to Shun Foreign Law in Courts Is Anti-Muslim," PilotOnline.com, January 21, 2012, available at: http:// hamptonroads.com/2012/01/critics-bill-shun-foreign-lawcourts-antimuslim.

${ }^{29}$ Kathy Adams, "Bills to Ban Use of Foreign Laws Rile Groups," PilotOnline.com, February 12, 2012, available at: http://hamptonroads.com/2012/02/bills-ban-use-foreign-laws-rile-groups.

30 Sean Cockerham, "Palmer Lawmaker's Bill Aimed at Islamic Law Called Divisive," Anchorage Daily News, March 30, 2011, available at: http://www.adn.com/2011/03/30/1784015/bill-to-stop-sharia-law-called.html.

31 David Montgomery, “On Sharia Law,” Rapid City Journal, February 5, 2011, available at: http://rapidcityjournal.com/blog/blogmore/on-sharia-law/article_b7d18641-fc3d-5050-a282700e7c3a854f.html.

32 Randy Lobasso, “Q\&A: Rep. RoseMarie Swanger, Who Introduced the ‘Anti-Sharia' Bill,” Philadelphia Weekly Blogs, December 22, 2011, available at: http://blogs.philadelphiaweekly.com/phillynow/2011/12/22/qa-reprosemarie-swanger-who-introduced-the- $\%$ E2\% $\% 0 \% 98$ anti-Sharia-law $\%$ E2\%80\%99-bill/.

33 Rosemarie Swanger, Letter to House Members on American and Pennsylvania Laws for Pennsylvania Courts-Shariah Law, June 14, 2011), available at: http://www.legis.state.pa.us/WU01/LI/CSM/2011/0/8559.pdf. 
34 Editorial, “Anti-Sharia Legislation Should End," The Times Herald, November 28, 2012, available at: http://www.thetimesherald.com/article/20121128/OPINION01/311280002/Anti-sharia-legislation-shouldend?nclick_check=1.

35 Susie Jones, "MN Muslims Protest Senate Bill, Claim Discrimination,” WCCO CBS Minnesota, March 5, 2012, available at: http://minnesota.cbslocal.com/2012/03/05/mn-muslims-protest-senate-bill-claim-

discrimination/.

36 Tim Lockette, "Legislation Would Ban Islamic Law in Alabama Courts," Anniston Star, March 4, 2011, available at: http://www.annistonstar.com/pages/full_story/push?article-

Legislation+would + ban +Islamic + law + in + Alabama + courts $-\%$ 20\&id $=12157691 \&$ instance $=$ recentComments.

${ }^{37}$ Ibid.

${ }^{38}$ Jonathan Oosting, "Again? Texas Legislator Claims Dearborn Home to Creeping Sharia, Authors Bill to 'Protect' his State,” MLive.com, April 14, 2011, available at: http://www.mlive.com/news/detroit/index.ssf/2011/04/this_again_texas_legislator_cl.html.

${ }^{39}$ Laura Leslie, "Legislating Because They Can?” NC Capitol (blog), WRAL, April 21, 2011, available at: http://www.wral.com/news/state/nccapitol/blogpost/9472465/.

${ }^{40}$ Noelle Phillips, "Senate Panel Debates Bill that Would Limit Sharia Law," The State, April 21, 2011, available at: http://www.thestate.com/2011/04/21/1786846/senate-panel-debates-bill-that.html (site discontinued).

${ }^{41}$ Lee Fang, "While South Carolina Proposes Ban On Sharia Law, Former State AG Says He’s Never 'Encountered' It," ThinkProgress, May 12, 2011, available at: http://thinkprogress.org/politics/2011/05/12/165623/south-carolina-sharia-ban-attorney-general/.

42 Steve Largen, "Legislation Tries to Bar Foreign Influence," Goupstate.com, February 4, 2011, available at: http://www.goupstate.com/article/20110204/articles/102041009?p=2\&tc=pg.

43 "Wyoming Legislation Targets Islamic, International Law," Billings Gazette, January 20, 2011, available at: http://billingsgazette.com/news/state-and-regional/wyoming/article_abc1a5ff-96dc-5b2e-ab34f46d4b68f0ec.html.

44 Jim Galloway, "Two Bills to Ban Sharia Law in Georgia Courts," Political Insider with Jim Galloway (blog), Atlanta Journal-Constitution, February 8, 2011, available at: http://blogs.ajc.com/political-insider-jimgalloway/2011/02/08/a-bill-to-ban-sharia-law-in-georgia-courts/.

${ }^{45}$ Jason Noble, "Missouri Legislators, Wary of Islamic Law, Propose Banning," Kansas City Star, March 12, 2011, available at: http://www.kansascity.com/2011/03/12/2723887/bills-would-bar-state-courts-from.html (site discontinued).

46 Andy Marso, "Lawmakers Urged to Address Sharia," The Topeka Capital-Journal, April 14, 2012, available at: http:/ / cjonline.com/news/2012-04-14/lawmakers-urged-address-sharia.

47 Adelle M. Banks, “Oklahoma Gov. Likes Revamped Anti-Sharia Bill,” The Oklahoman, March 22, 2011. 